\title{
Ethanol processor design for hydrogen production. Kinetic analysis and process integration
}

Eduardo Izurieta, M. Esperanza Adrover, Marisa N. Pedernera, and Eduardo Lopez

Ind. Eng. Chem. Res., Just Accepted Manuscript • DOI: 10.1021/acs.iecr.8b02324 • Publication Date (Web): 24 Sep 2018

Downloaded from http://pubs.acs.org on September 27, 2018

\section{Just Accepted}

"Just Accepted" manuscripts have been peer-reviewed and accepted for publication. They are posted online prior to technical editing, formatting for publication and author proofing. The American Chemical Society provides "Just Accepted" as a service to the research community to expedite the dissemination of scientific material as soon as possible after acceptance. "Just Accepted" manuscripts appear in full in PDF format accompanied by an HTML abstract. "Just Accepted" manuscripts have been fully peer reviewed, but should not be considered the official version of record. They are citable by the Digital Object Identifier (DOI®). "Just Accepted" is an optional service offered to authors. Therefore, the "Just Accepted" Web site may not include all articles that will be published in the journal. After a manuscript is technically edited and formatted, it will be removed from the "Just Accepted" Web site and published as an ASAP article. Note that technical editing may introduce minor changes to the manuscript text and/or graphics which could affect content, and all legal disclaimers and ethical guidelines that apply to the journal pertain. ACS cannot be held responsible for errors or consequences arising from the use of information contained in these "Just Accepted" manuscripts. 


\title{
Ethanol processor design for hydrogen production.
}

\section{Kinetic analysis and process integration}

\author{
Eduardo M. Izurieta ${ }^{1,2}$, M. Esperanza Adrover ${ }^{1,2}$, Marisa N. Pedernera ${ }^{1,2}$, Eduardo López ${ }^{2}$ \\ 1 Departamento de Ingeniería Química, Universidad Nacional del Sur (UNS), Bahía Blanca 8000 \\ Argentina \\ 2 Planta Piloto de Ingeniería Química - PLAPIQUI (Universidad Nacional del Sur-CONICET), Bahía \\ Blanca, Buenos Aires 8000, Argentina \\ *eizurieta@plapiqui.edu.ar
}

\begin{abstract}
Keywords: Ethanol steam reforming; Kinetic analysis; Nickel-based catalyst; Parallel plates reactor; Pd-based Membrane;
\end{abstract}

\begin{abstract}
A kinetic study of ethanol steam reforming was conducted with a commercial nickel-based catalyst. The reaction was studied at atmospheric pressure, with temperatures varying from 550 to $650^{\circ} \mathrm{C}$, and residence times up to $25 \mathrm{~h} \cdot \mathrm{g} / \mathrm{Nm}^{3}$. From the analysis of the product distribution, a scheme of reactions was proposed and used to simulate a pseudohomogeneous reactor and fit the kinetic parameters. Results show good fitting with the measured data. The kinetic expressions were profited towards the design of an integrated process of $\mathrm{H}_{2}$ production from ethanol which includes a parallel-plates reactor, a shell-andtubes membrane unit and auxiliary units. Results showed satisfactory thermal integration with efficiencies from 43 to $47 \%$ based on LHV values and from 52 to $57 \%$ based on HHV values. For three different simulation scenarios, outlet streams of about $10 \mathrm{~mol}_{\mathrm{H} 2} / \mathrm{h}$ were obtained. The proposed scheme


showed robustness, accepting significant variations in the set conditions, and still maintaining the process operability.

\section{Introduction}

In the search of renewable energy sources, hydrogen is presented as an interesting alternative to fossil fuels, especially when it proceeds from biological raw materials ${ }^{1}$. The main problem of this energy vector is its difficulty to be stored both in gas or liquid state, mainly for mobile applications, turning it into a technical bottleneck in the development of non-stationary fuel cell technologies ${ }^{2}$. The use of a liquid fuel from which produce hydrogen directly on-demand could contribute to the solution of this technological issue. Concerning this, ethanol appears as an auspicious raw material since it presents easy storage, low toxicity and it possesses high energy density ${ }^{3}$. First-generation bioethanol is achieved from fermentation of cereals, sugar cane or beetroot, among others ${ }^{4,5}$. Interestingly, second-generation bioethanol can be obtained from non-food sources as non-food energy crops grown on marginal land unsuitable for crop production or from lignocellulosic biomass. This second-generation bioethanol is much more appealing than the first-generation one in terms of environmental issues and human health ${ }^{6}$. Furthermore, the bioethanol introduction as a carrier of energy could reduce the carbon dioxide emissions about $30 \%{ }^{7}$. Catalytic ethanol steam reforming (ESR) is pointed as an excellent candidate to produce hydrogen/syngas, looking for diminishing the use of non-renewable sources, as natural gas. Some first approaches to this reaction were done in the early $1990 \mathrm{~s}^{8}$, and since then, a considerable effort has been put into intensifying the knowledge about the mechanism of the ethanol steam reforming reaction and avoiding/mitigating catalyst deactivation ${ }^{9-11}$. Several different catalysts have been tested to develop optimal process implementations ${ }^{12}$. Then, it is necessary for each ESR catalyst, to study its 
performance and mechanism, and to propose and adjust a reaction rate expression useful at the time of either design the reactor or optimize the global process.

On the other hand, the global process integration represents itself another key point in the design of a fuel cell system. With the idea of achieving self-sustainability and minimize the use of external resources, fuel cell systems could present highly energetic integration if they are optimally designed ${ }^{13}$. Through an energetic optimization, the process has been reported to achieve an energetic efficiency of $38 \%{ }^{14}$, including, in this case, the efficiency of the fuel cell itself. A general layout for these kind of processes includes a fuel processor, hydrogen purification, the fuel cell itself, combustion system, and heat exchanger networks ${ }^{12}$. It is reported that the efficiency could be incremented an extra $5 \%$ if the $\mathrm{H}_{2}$ purification is made with membrane-based systems ${ }^{15}$.

This work presents reaction experiences of ethanol steam reforming over a commercial nickel-based monolithic catalyst under relevant and realistic operating conditions. Based on the results, a scheme of reactions satisfying the experimental observations is proposed and the data are used to fit the kinetic parameters of power-law-type expressions of the reaction rates. Subsequently, the adjusted kinetic model is profited towards the design and simulation of a complete ethanol processor for clean hydrogen production including evaporation, reaction, hydrogen permeation and thermal integration to feed a PEM fuel cell with a stream of $10 \mathrm{~mol}_{\mathrm{H} 2} / \mathrm{h}$.

\section{Material and methods}

\subsection{Catalyst}

A monolithic commercial catalyst (ceramic, square channels, 400 cspi) was selected to carry out the ethanol steam reforming reaction. A washcoat thickness of about $40 \mu \mathrm{m}$ in the central zone was estimated via SEM images (JEOL 35 CF), as presented in Figure 1. XRF (Magi'X with rhodium anode, 
crystals of FLi 200, LiF220, Ge, PX1, PX4, PE, and detectors of flow and scintillation) and XRD (Philips PW 1710, cupper anode and graphite monochromator) analyses were performed towards a preliminary characterization of the washcoat. The results revealed that nickel is the active metal (ca. $23 \% \mathrm{w} / \mathrm{w}$ ) over a support of $\mathrm{CeO}_{2} / \mathrm{Al}_{2} \mathrm{O}_{3}$.

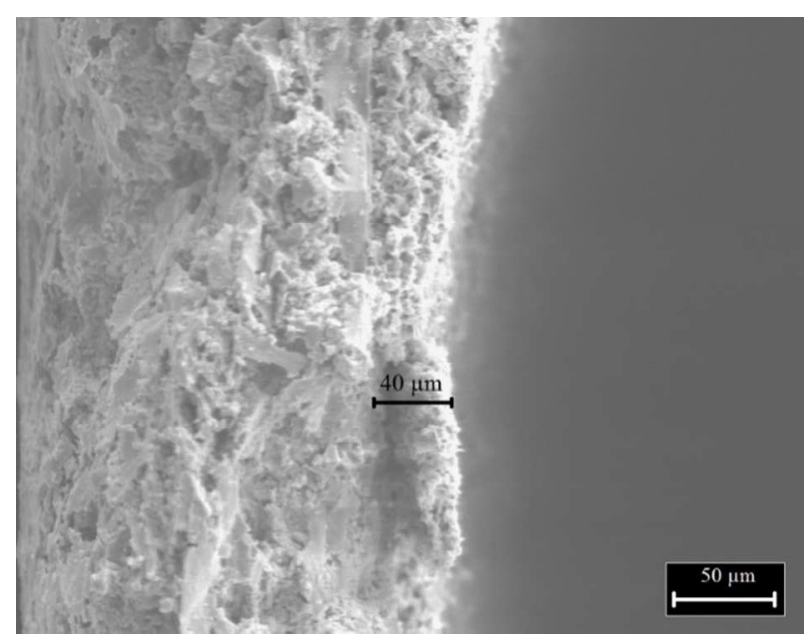

Figure 1. SEM image of the washcoat.

To evaluate the catalyst performance in reaction conditions, the catalytic washcoat was mechanically extracted from the monolith. The particle size distribution of the obtained powder was measured in homogenized suspensions by laser light diffraction using a Horiba LA-950 V2 device. The average particle size was $10.8 \mu \mathrm{m}$ and the D90 parameter resulted $14.4 \mu \mathrm{m}$, i.e., $90 \%$ of the sample is below this value.

The load of washcoat in the original monolith is of ca. $3.96 \mathrm{mg} / \mathrm{cm}^{2}$, which was estimated from the weight difference between the original commercial monolith and a fresh cordierite sample (same geometrical characteristics). This value is profited below towards the reactor design and simulation.

\subsection{Catalytic runs}


All the reaction tests were conducted in a fully-automated kinetic unit (Microactivity Effi, Fig. 2). The experimental system includes the injection and evaporation of the liquid mixture (ethanol/water), electrical heating, and effluents collection, both gaseous and liquid. The liquid feed mixture was injected with a HPLC pump (Gilson 307). An electrical oven with electronic temperature control was used to thermostat the stainless-steel reactor (inner diameter $9 \mathrm{~mm}$ ) where the powder catalyst was disposed. A K-type thermocouple was placed directly inside the catalytic bed to register and control the reaction temperature. The condensable compounds exiting the reactor were separated and collected by means of a condenser at $10^{\circ} \mathrm{C}$ using a Peltier-based device. The non-condensable fraction was quantified by gaseous chromatography (HP 4890D) using Porapak QS-AW and Molecular Sieve $5 \AA$ columns, and TCD. Moreover, the total volumetric flowrate of the gaseous stream and the liquid condensation rate were quantified in order to close element balances and ensure the reliability of the experiments.

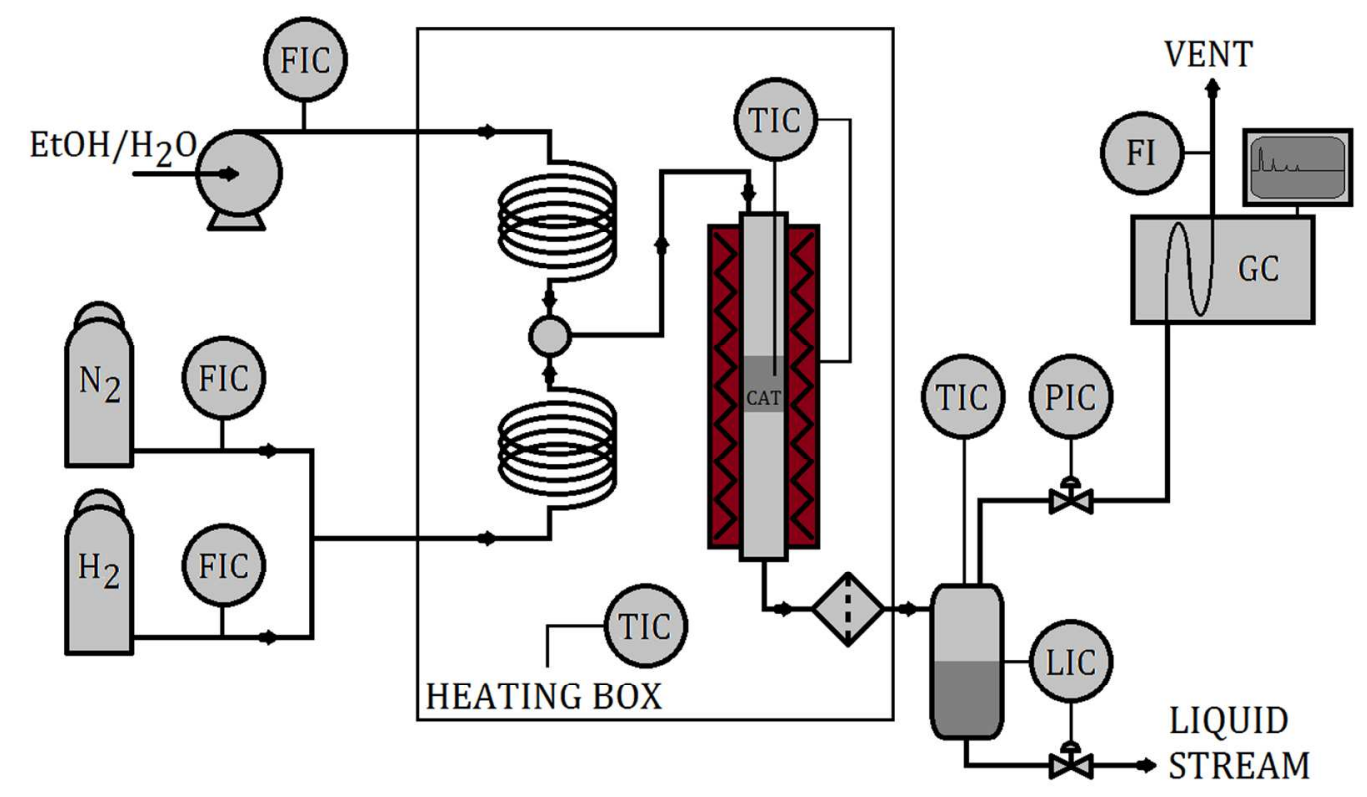

Figure 2. Experimental setup.

$50 \mathrm{mg}$ of powder catalyst was used to evaluate the catalytic performance in the ESR reaction. The samples were diluted with quartz in a ratio 7:1 (quartz:catalyst,w/w) in order to diminish the thermal 
effects of the reaction. All experiences were performed at a pressure of 1.13 bar. Before the runs, the catalyst was reduced at $600^{\circ} \mathrm{C}$ (heating rate $10^{\circ} \mathrm{C} / \mathrm{min}$ ) for 1 hour, in $10 \% \mathrm{H}_{2} / \mathrm{N}_{2}$, with a total flowrate of $100 \mathrm{~mL} / \mathrm{min}$. In all cases, the reactions were carried out with a molar ratio of water to ethanol of 6 , to avoid or minimize carbon formation and subsequent catalyst deactivation. The experiments were performed at temperatures in the range $550-650^{\circ} \mathrm{C}$, and with residence times up to $25 \mathrm{~h} \cdot \mathrm{g} / \mathrm{Nm}^{3}$ ( $(\mathrm{see}$ definition in Eq. 1). For each test, steady state was reached after about 45 minutes and the operation was maintained for at least 2 hours to ensure stability and repeatability. The results of the catalytic tests are expressed in terms of ethanol or water conversion ( $X_{i}$, Eq. 2$)$ and products yield ( $Y_{i}$, Eq. 3$)$.

$\tau=\frac{W}{\dot{V}}$

$X_{i}=\frac{F_{i}^{0}-F_{i}}{F_{i}^{0}} \cdot 100 \quad i=\mathrm{C}_{2} \mathrm{H}_{5} \mathrm{OH}, \mathrm{H}_{2} \mathrm{O}$

$Y_{i}=\frac{F_{i}}{F_{C_{2} \mathrm{H}_{5} \mathrm{OH}}^{0}} \quad i=\mathrm{C}_{2} \mathrm{H}_{5} \mathrm{OH}, \mathrm{H}_{2} \mathrm{O}, \mathrm{H}_{2}, \mathrm{CO}_{2}, \mathrm{CH}_{4}, \mathrm{CO}, \mathrm{C}_{2} \mathrm{H}_{4} \mathrm{O}$

where $F_{i}$ is the molar flowrate of species $i(\mathrm{~mol} / \mathrm{min}), W$ is the mass of catalyst $(\mathrm{g})$ and $\dot{V}$ is the volumetric flowrate of the inlet stream $\left(\mathrm{Nm}^{3} / \mathrm{h}\right)$.

\subsection{Kinetic model and parameters fitting}

According to references in literature ${ }^{16}$, experimental observations regarding the ethanol steam reforming over Ni-based catalysts can be represented by ethanol dehydrogenation (EDH), ethanol decomposition (ED), acetaldehyde decomposition (AD), acetaldehyde steam reforming (ASR), methane steam reforming to $\mathrm{CO}_{2}$ (MSR) and water gas shift (WGS):

EDH:

$$
\begin{array}{lrl}
\text { EDH: } & \mathrm{C}_{2} \mathrm{H}_{5} \mathrm{OH} \rightarrow \mathrm{C}_{2} \mathrm{H}_{4} \mathrm{O}+\mathrm{H}_{2} \\
\text { ED: } & \mathrm{C}_{2} \mathrm{H}_{5} \mathrm{OH} \rightarrow 0.5 \mathrm{CO}+1.5 \mathrm{CH}_{4}
\end{array}
$$$$
\text { AD: } \quad \mathrm{C}_{2} \mathrm{H}_{4} \mathrm{O} \rightarrow \mathrm{CO}+\mathrm{CH}_{4}
$$ 
ASR:

$$
\mathrm{C}_{2} \mathrm{H}_{4} \mathrm{O}+\mathrm{H}_{2} \mathrm{O} \rightarrow 2 \mathrm{CO}+3 \mathrm{H}_{2}
$$

MSR:

$$
\mathrm{CH}_{4}+2 \mathrm{H}_{2} \mathrm{O} \leftrightarrow \mathrm{CO}_{2}+4 \mathrm{H}_{2}
$$

WGS:

$$
\mathrm{CO}+\mathrm{H}_{2} \mathrm{O} \leftrightarrow \mathrm{CO}_{2}+\mathrm{H}_{2}
$$

A steady-state 1-D pseudohomogeneous mathematical model was implemented here to represent the laboratory reactor aiming the kinetic parameter fitting of the already presented reaction system (Eqs. 49). Mass transfer limitations were initially neglected to accomplish the kinetic fitting. Once the reaction rates were available, they were used along with the size of the catalyst particles to check the original assumption according to theoretical criteria developed by Gonzo ${ }^{17}$. A power-law model was selected to represent the kinetic mechanism. The model is assumed to be isothermal and isobaric. The system of simultaneous equations is the following:

$$
\begin{gathered}
\frac{d F_{i}}{d W}=\sum_{j}\left(v_{i j} \cdot r_{j}\right) \\
r_{E D H}=k_{E D H} \cdot p_{C_{2} H_{5} O H} \\
r_{E D}=k_{E D} \cdot p_{C_{2} H_{5} O H} \\
r_{A D}=k_{A D} \cdot p_{C_{2} H_{4} O} \\
r_{A S R}=k_{A S R} \cdot p_{C_{2} H_{4} O} \cdot p_{H_{2} O} \\
r_{M S R}=k_{M S R} \cdot\left(p_{C H_{4}} \cdot p_{H_{2} O}^{2}-\frac{p_{C O_{2}} \cdot p_{H_{2}}^{4}}{K_{e q, M S R}}\right) \\
r_{W G S}=k_{W G S} \cdot\left(p_{C O} \cdot p_{H_{2} O}-\frac{p_{C O_{2}} \cdot p_{H_{2}}}{K_{e q, W G S}}\right) \\
k_{j}=k_{j}^{0} \cdot \exp \left(\frac{-E_{j}}{R} \cdot\left(\frac{1}{T}-\frac{1}{T^{r e f}}\right)\right)
\end{gathered}
$$

873.15 K was selected here as temperature of reference $\left(\mathrm{T}^{\mathrm{ref}}\right)$. The equilibrium constants are taken from literature ${ }^{18}$ and are expressed as follows: 


$$
\begin{gathered}
\log _{10}\left(K_{e q, M S R}\right)=\frac{1910}{T}-\frac{11650}{T}+11.292 \\
\log _{10}\left(K_{e q, W G S}\right)=\frac{1910}{T}-1.784
\end{gathered}
$$

The kinetic constants and activation energies were adjusted with gPROMS ${ }^{19}$. The objective function of the fitting procedure is:

$$
\Phi=\frac{N}{2} \ln (2 \pi)+\frac{1}{2} \min _{\theta}\left\{\sum_{i=1}^{N E} \sum_{j=1}^{N V_{i}} \sum_{k=1}^{N M_{i j}}\left[\ln \left(\sigma_{i j k}^{2}\right)+\frac{\left(\hat{z}_{i j k}-z_{i j k}\right)^{2}}{\sigma_{i j k}^{2}}\right]\right\}
$$

where $N$ is the total number of measurements taken throughout the experiments, $\theta$ is the set of model parameters to be estimated, $N E$ is the number of performed experiments, $N V_{i}$ is the number of measured variables in the $i^{\text {th }}$ experiment, $N M_{i j}$ is the number of measurements of the $j^{\text {th }}$ variable in the $i^{t h}$ experiment, $\sigma_{i j k}^{2}$ is the variance of the $k^{\text {th }}$ measurement of variable $j$ in experiment $i, \hat{z}_{i j k}$ is the $k^{t h}$ measured value of variable $j$ in experiment $i$, and $z_{i j k}$ is the $k^{\text {th }}$ model-predicted value of variable $j$ in experiment $i$.

\section{Reaction Results}

For the selected experimental conditions, the observed reaction products were $\mathrm{H}_{2}, \mathrm{CO}_{2}, \mathrm{CH}_{4}$ and $\mathrm{CO}$. For experiences at high temperature and/or residence times, total absence of acetaldehyde was measured in the outlet stream. Conversely, experiences with low residence times evidenced minor amounts of acetaldehyde. Only few experiences (at low $\mathrm{T}$ and $\tau$ ) showed negligible quantities of ethylene; therefore, it was excluded from the kinetic scheme. As not carbon depositions were expected for the selected operating conditions (i.e., elevated temperatures and great excess of water), ethanol, water and acetaldehyde amounts were calculated for the condensate phase by closure of elements balance. Results are presented in Figures 3A, B and C, respectively. As shown, both ethanol and water conversions 
increase with temperature and residence time. Complete ethanol conversion is achieved for all temperatures with residence times high enough. Acetaldehyde is formed very fast, but its consumption is even faster, and the yield of this species remains low in all cases $\left(\mathrm{Y}_{\mathrm{C}_{2} \mathrm{H} 4 \mathrm{O}}<0.01 \mathrm{~mol} / \mathrm{mol}_{\mathrm{C} 2 \mathrm{H} 5 \mathrm{OH}}\right)$.
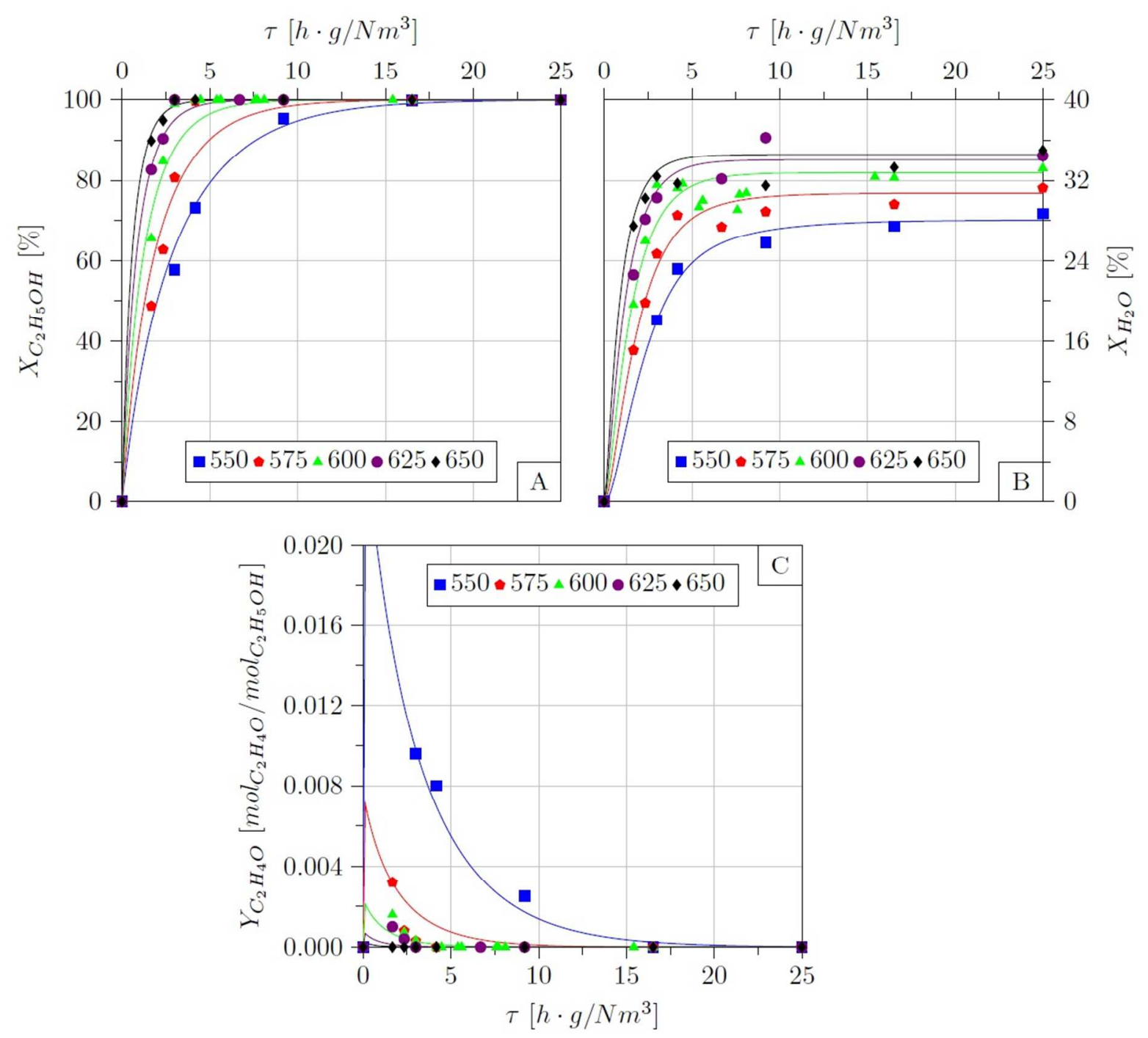

Figure 3. Ethanol (A) and water (B) conversion, and acetaldehyde yield (C). Continuous lines represent the results of the mathematical model of the reactor.

Figures $4 \mathrm{~A}$ to $4 \mathrm{D}$ show the evolution of the $\mathrm{H}_{2}, \mathrm{CO}_{2}, \mathrm{CH}_{4}$ and $\mathrm{CO}$ yields with residence time and temperature. While production of $\mathrm{H}_{2}$ seems to increase monotonically with both residence time and 
temperature, the $\mathrm{CH}_{4}$ yield present a maximum which is coincident with experiences where the ethanol consumption is not complete. The maximum in the $\mathrm{CO}$ yield at low temperatures is due to the $\mathrm{CO}$ formation from the $\mathrm{ED}$ or $\mathrm{AD}$ reactions and its consumption through WGS reaction. At higher temperature, CO yield augments monotonically since WGS reaction proceeds backwards due to its exothermic nature. This effect is also appreciated in the $\mathrm{CO}_{2}$ yield, which seems to have a maximum with respect to the temperature at about $625^{\circ} \mathrm{C}$.
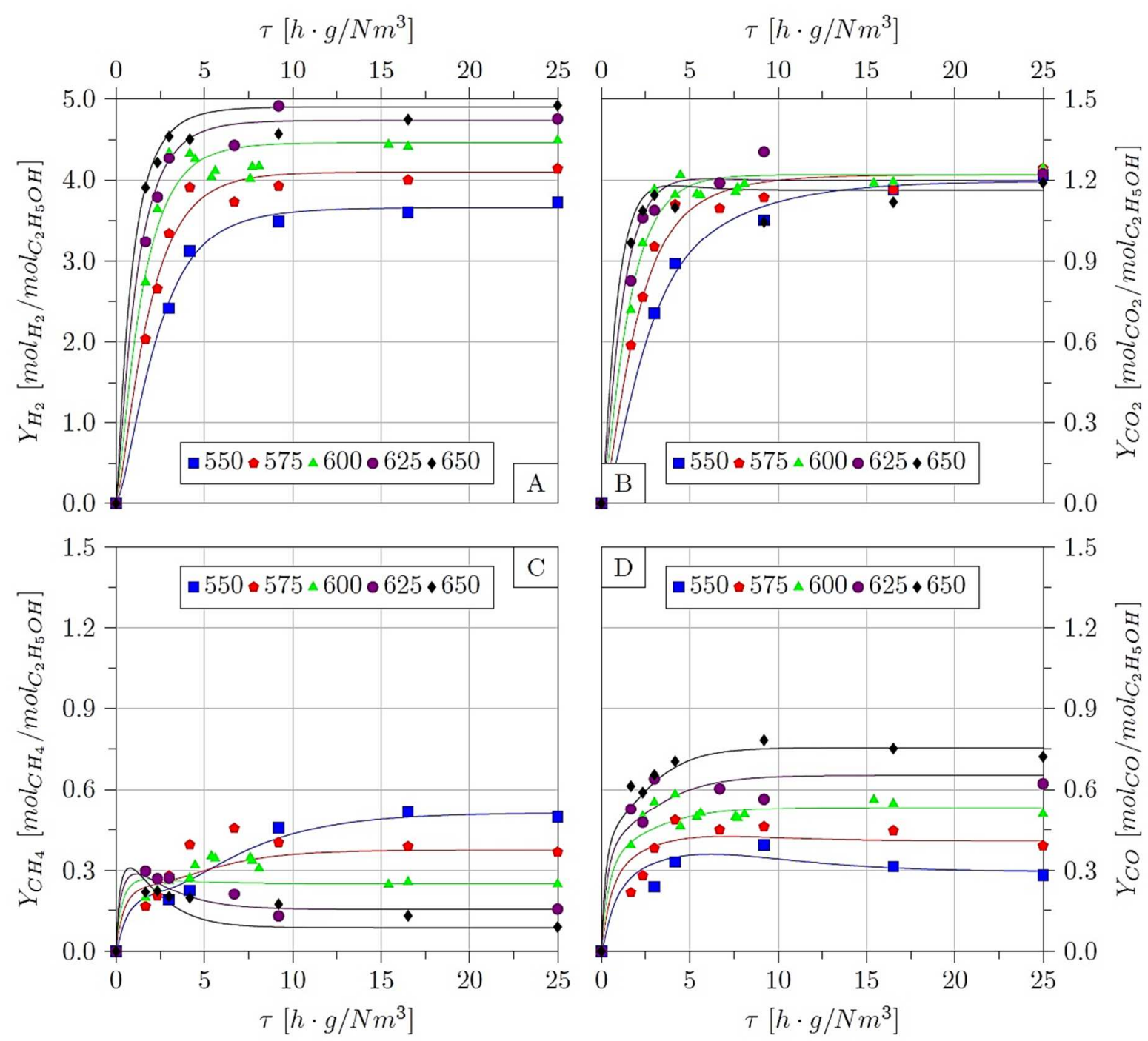

Figure 4. Evolution of (A) $\mathrm{H}_{2}$, (B) $\mathrm{CO}_{2}$, (C) $\mathrm{CH}_{4}$, (D) $\mathrm{CO}$. Continuous lines represent the results 
of the mathematical model of the reactor.

The experimental studies described above were complemented with a 24-h stability test (see Figure 5). The experience was performed in 4 stages of 6-h each, maintaining an inert atmosphere $\left(\mathrm{N}_{2}\right)$ among each operative day. The results show a remarkably stable operation, with high repeatability of the measurements. Ethanol conversion was complete along the whole test and low dispersion was found in the yields to the gaseous products.

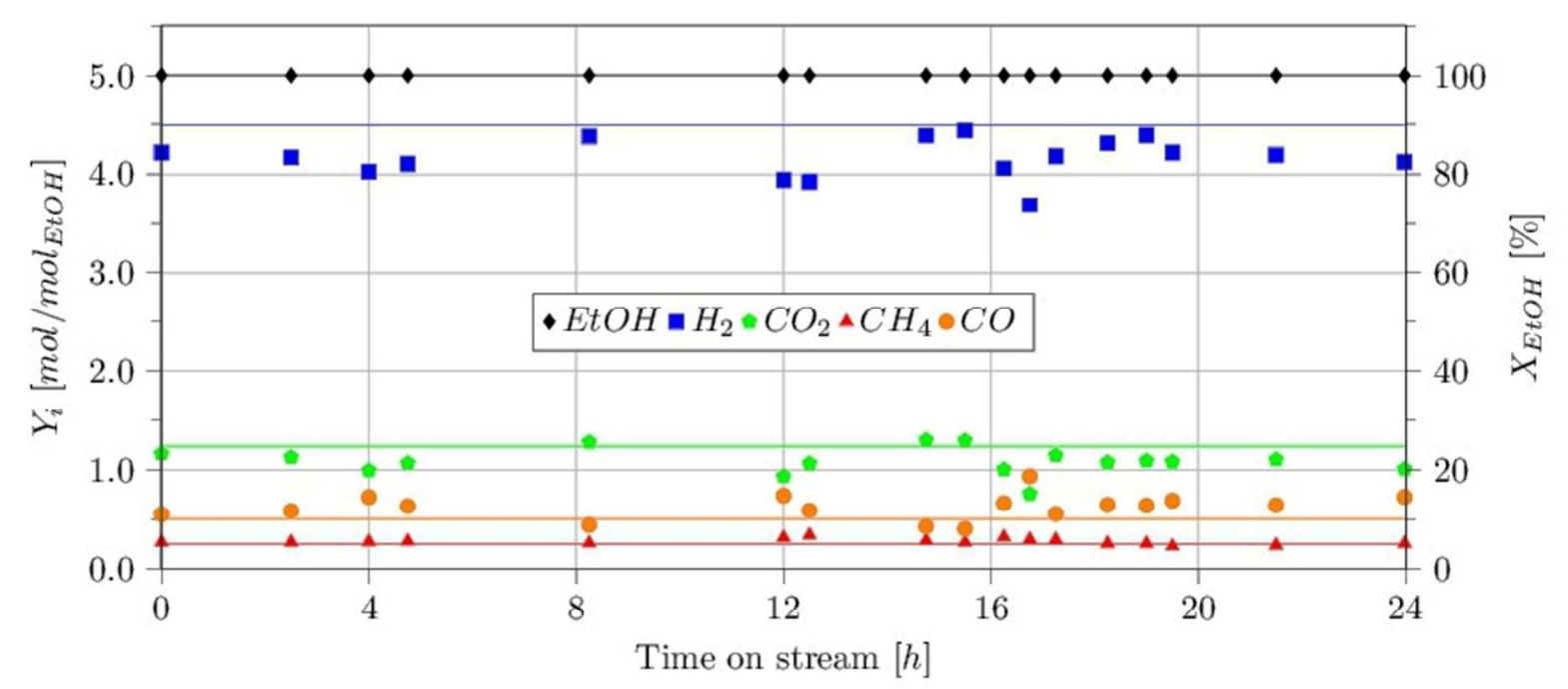

Figure 5. Stability test (yield to products, ethanol conversion) at $\mathrm{T}=600^{\circ} \mathrm{C}$ and $\tau=16 \mathrm{~h} \cdot \mathrm{g} / \mathrm{Nm}^{3}$. Continuous lines represent the results of the mathematical model of the reactor.

The results of the parameter estimation procedure, along with their correspondent standard deviations, are presented in Table 1. Two of the proposed reactions (ED and ASR) were omitted in the final scheme since the values of the kinetic constants were statistically non-different from 0 . Moreover, the parity chart of molar flows (calculated vs. measured) is shown in Figures 6A and 6B. 


\begin{tabular}{|l|l|l|}
\hline Reaction & $k_{j}^{0}\left[\mathrm{~mol} /\left(\mathrm{h} \cdot \mathrm{g} \cdot \mathrm{bar}^{\mathrm{n}}\right)\right]$ & $E_{j}[\mathrm{~kJ} / \mathrm{mol}]$ \\
\hline EDH (n: 1) & $35.6 \pm 1.0$ & $101.2 \pm 6.2$ \\
\hline AD (n: 1) & $15130 \pm 4200$ & $388.4 \pm 35.1$ \\
\hline MSR (n: 3) & $119.8 \pm 6.8$ & $75.0 \pm 11.7$ \\
\hline WGS (n: 2) & $55.1 \pm 4.7$ & $64.0 \pm 9.9$ \\
\hline $\mathrm{R}^{2}: 0.988$ & & \\
\hline
\end{tabular}

Table 1. Results of the parameter estimation.

As seen in Figures 3-6, the achieved results present an overall reliable approximation to the experimental data. The values of the fitted activation energies were found to be in the range of those reported in the literature, as exposed in Tables 2 to 5.
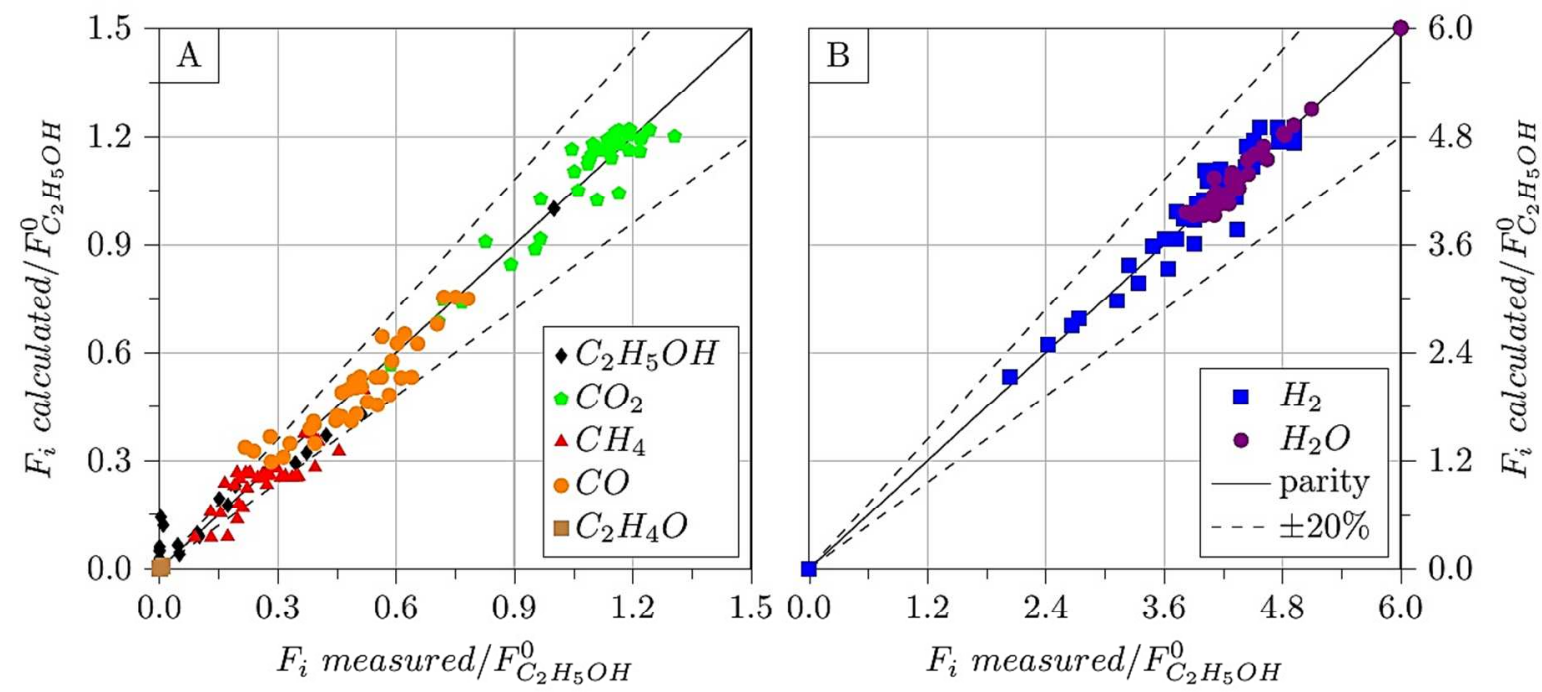

Figure 6. Parity plots of $(\mathrm{A}) \mathrm{C}_{2} \mathrm{H}_{5} \mathrm{OH}, \mathrm{CO}, \mathrm{CH}_{4}, \mathrm{CO}_{2}$ and $\mathrm{C}_{2} \mathrm{H}_{4} \mathrm{O}$, and $(\mathrm{B}) \mathrm{H}_{2}$ and $\mathrm{H}_{2} \mathrm{O}$. 


\begin{tabular}{|l|l|l|}
\hline $\boldsymbol{C}_{\mathbf{2}} \boldsymbol{H}_{\mathbf{5}} \mathrm{OH} \rightarrow \boldsymbol{C}_{\mathbf{2}} \boldsymbol{H}_{\mathbf{4}} \boldsymbol{O}+\boldsymbol{H}_{\mathbf{2}}$ & Catalyst & $\boldsymbol{E}[\mathrm{kJ} / \mathbf{m o l}]$ \\
\hline This work & $\mathrm{Ni} / \mathrm{Al}_{2} \mathrm{O}_{3}-\mathrm{CeO}_{2}$ & 101.2 \\
Palma et al. (2014) & $\mathrm{Ni}-\mathrm{Pt} / \mathrm{CeO}_{2}$ & 74.0 \\
Morgenstern and Fornago (2005) & $\mathrm{Ni}-\mathrm{Cu}$ & 149.0 \\
García et al. (2009) $^{22}$ & $\mathrm{SnO}_{2}$ & 66.0 \\
\hline
\end{tabular}

Table 2. Comparison of $E_{E D H}$ from different authors.

\begin{tabular}{|l|l|l|}
\hline $\boldsymbol{C}_{\mathbf{2}} \boldsymbol{H}_{\mathbf{4}} \boldsymbol{O} \rightarrow \boldsymbol{C O}+\boldsymbol{C H}_{4}$ & Catalyst & $\boldsymbol{E}[\mathrm{kJ} / \mathbf{m o l}]$ \\
\hline This work & $\mathrm{Ni} / \mathrm{Al}_{2} \mathrm{O}_{3}-\mathrm{CeO}_{2}$ & 388.4 \\
Palma et al. (2014) ${ }^{20}$ & $\mathrm{Ni}-\mathrm{Pt} / \mathrm{CeO}_{2}$ & 181.0 \\
\hline
\end{tabular}

Table 3. Comparison of $E_{A D}$ from different authors.

\begin{tabular}{|l|l|l|}
\hline $\boldsymbol{C H}_{\mathbf{4}}+\mathbf{2} \mathrm{H}_{\mathbf{2}} \mathrm{O} \leftrightarrow \boldsymbol{C O}_{2}+\mathbf{4} \mathbf{H}_{2}$ & Catalyst & $\boldsymbol{E}[\mathrm{kJ} / \mathbf{m o l}]$ \\
\hline This work & $\mathrm{Ni} / \mathrm{Al}_{2} \mathrm{O}_{3}-\mathrm{CeO}_{2}$ & 75.0 \\
Mas et al. (2008) & $\mathrm{Ni}-\mathrm{Al}-\mathrm{O}$ & 123.5 \\
Hou et al. (2001) & $\mathrm{Ni} / \mathrm{Al}_{2} \mathrm{O}_{3}$ & 109.4 \\
Wei and Iglesia (2004) $^{25}$ & $\mathrm{Ni} / \mathrm{MgO}$ & 102.0 \\
\hline
\end{tabular}

Table 4. Comparison of $E_{M S R}$ from different authors.

\begin{tabular}{|c|c|c|}
\hline $\mathrm{CO}+\mathrm{H}_{2} \mathrm{O} \leftrightarrow \mathrm{CO}_{2}+\mathrm{H}_{2}$ & Catalyst & $E[\mathrm{~kJ} / \mathrm{mol}]$ \\
\hline This work & $\mathrm{Ni} / \mathrm{Al}_{2} \mathrm{O}_{3}-\mathrm{CeO}_{2}$ & 64.0 \\
\hline López et al. (2012) ${ }^{26}$ & $\mathrm{Pd} / \mathrm{Al}_{2} \mathrm{O}_{3}$ & 59.9 \\
\hline Sahoo et al. (2007) ${ }^{27}$ & $\mathrm{Co} / \mathrm{Al}_{2} \mathrm{O}_{3}$ & 71.3 \\
\hline $\mathrm{Xu}$ and Froment (1989) ${ }^{28}$ & $\mathrm{Ni} / \mathrm{MgAl}_{2} \mathrm{O}_{4}$ & 67.3 \\
\hline
\end{tabular}


Table 5. Comparison of $E_{W G S}$ from different authors.

The experience presenting the highest reaction rate $\left(\mathrm{T}=650^{\circ} \mathrm{C}\right.$ and $\left.\tau=1.67 \mathrm{~h} \cdot \mathrm{g} / \mathrm{Nm}^{3}\right)$ was selected to check the criteria to neglect mass transport limitations. The highest reaction rate was found to be for MSR reaction. Gonzo's criteria ${ }^{17}$ establish that kinetic control is satisfied if the following relation applies:

$$
\frac{r_{M S R} \cdot R_{O}^{2}}{D_{e} \cdot C_{C H_{4}}} \leq \frac{0.9}{\sigma}
$$

For our case, the left-hand side of Eq. 21 was found to be 0.12 while the right-hand side was 0.79 . Therefore, mass transport limitations can be neglected. As already stated, the adjusted kinetic parameters must be adapted to the monolithic geometry for subsequent modelling purposes. Considering the value of $3.96 \mathrm{mg} / \mathrm{cm}^{2}$, Table 6 shows the equivalent parameters which should be used to model a monolithic reactor. These equivalent values assume null internal diffusion limitations due to the low thickness of the washcoat ${ }^{29}$.

\begin{tabular}{|l|l|}
\hline Reaction & $\boldsymbol{k}_{\boldsymbol{j}}^{\mathbf{0}}\left[\mathbf{m o l} /\left(\mathbf{h} \cdot \mathbf{m}^{\mathbf{2}} \cdot \mathbf{b a r}^{\mathbf{n}}\right)\right]$ \\
\hline EDH & 1408.4 \\
\hline AD & 599200 \\
\hline MSR & 4744.1 \\
\hline WGS & 2180.1 \\
\hline
\end{tabular}

Table 6. Equivalent parameters to be used in the monolithic reactor model.

\section{Process integration}

The obtained kinetic parameters were employed to design and simulate a complete ethanol processor including evaporation, reaction and hydrogen purification, aiming to feed a PEM fuel cell with a 
flowrate of $10 \mathrm{~mol}_{\mathrm{H} 2} / \mathrm{h}$, saturated in water. A simplified scheme of the simulated process (slight modification from ref. ${ }^{12}$ ) is presented in Figure 7.

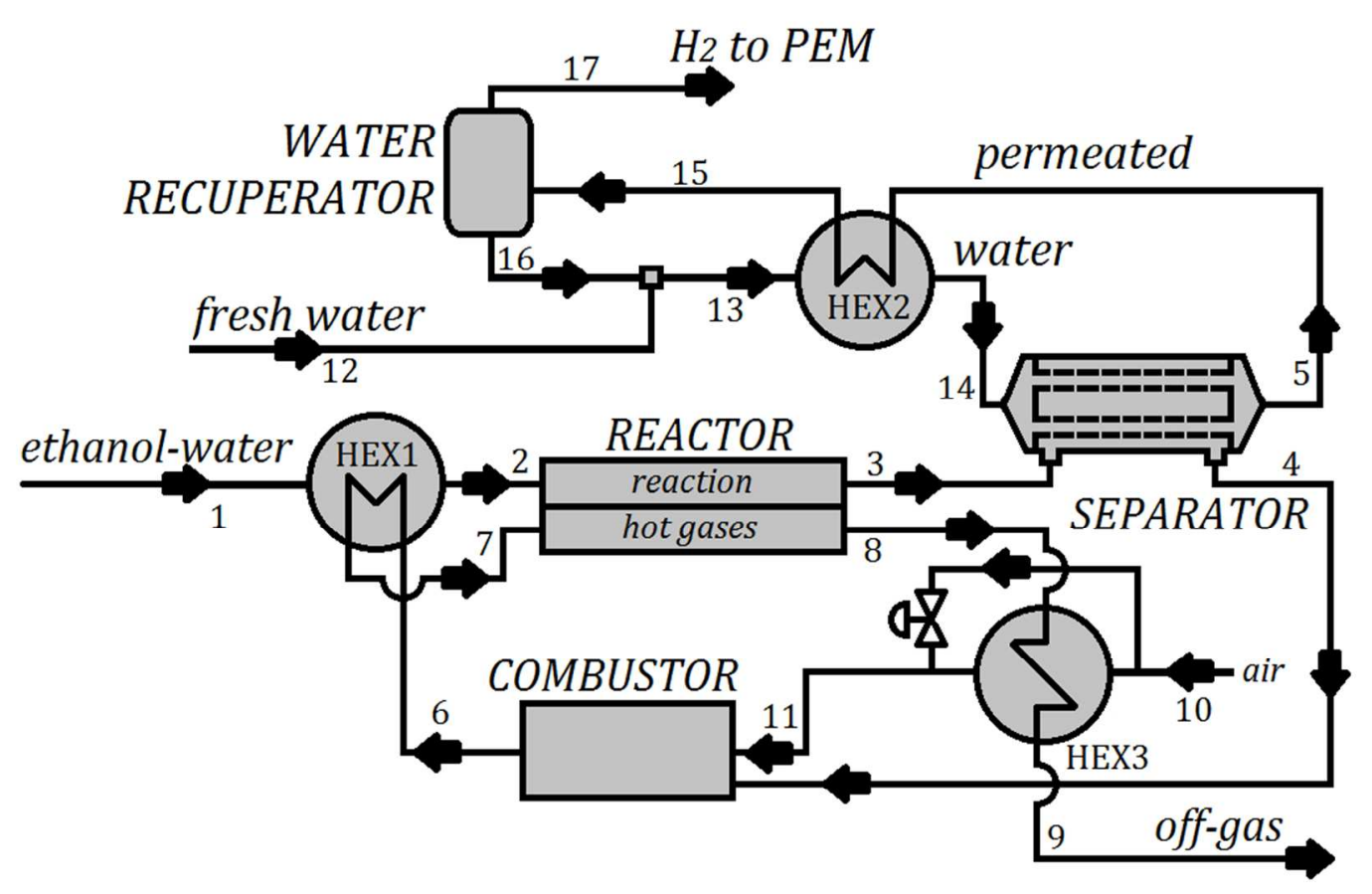

Figure 7. Scheme of the simulated process.

\subsection{Parallel-plates reactor}

A one-dimensional heterogeneous model is selected to represent a parallel plates reactor where the hydrogen generation is intended. Figure $8 \mathrm{~A}$ presents a schematic representation of the simulated reactor. The unit is constituted of alternated sections of monolithic structures which are separated by a metallic wall of thickness $\mathrm{L}_{\mathrm{W}}$. Ceramic monolithic catalysts washcoated with the active phase studied in Section 3, with square channels of width $L_{X}$ and length $L_{R}$, are disposed inside the sections devoted to ethanol steam reforming. Conversely, while a stream of hot gases flowing co-currently through bare cordierite 
monolith disposed in the alternate sections supplies the reaction heat through the metallic walls. The reactor is considered to be perfectly isolated from the environment (i.e., adiabatic reactor).

Steady state operation along with neglectable pressure drop and perfectly distributed flux in all channels are assumed. Axial thermal conduction through the monoliths is neglected, based on both the low crosssectional area and the low conductivity of the ceramic material at hand.

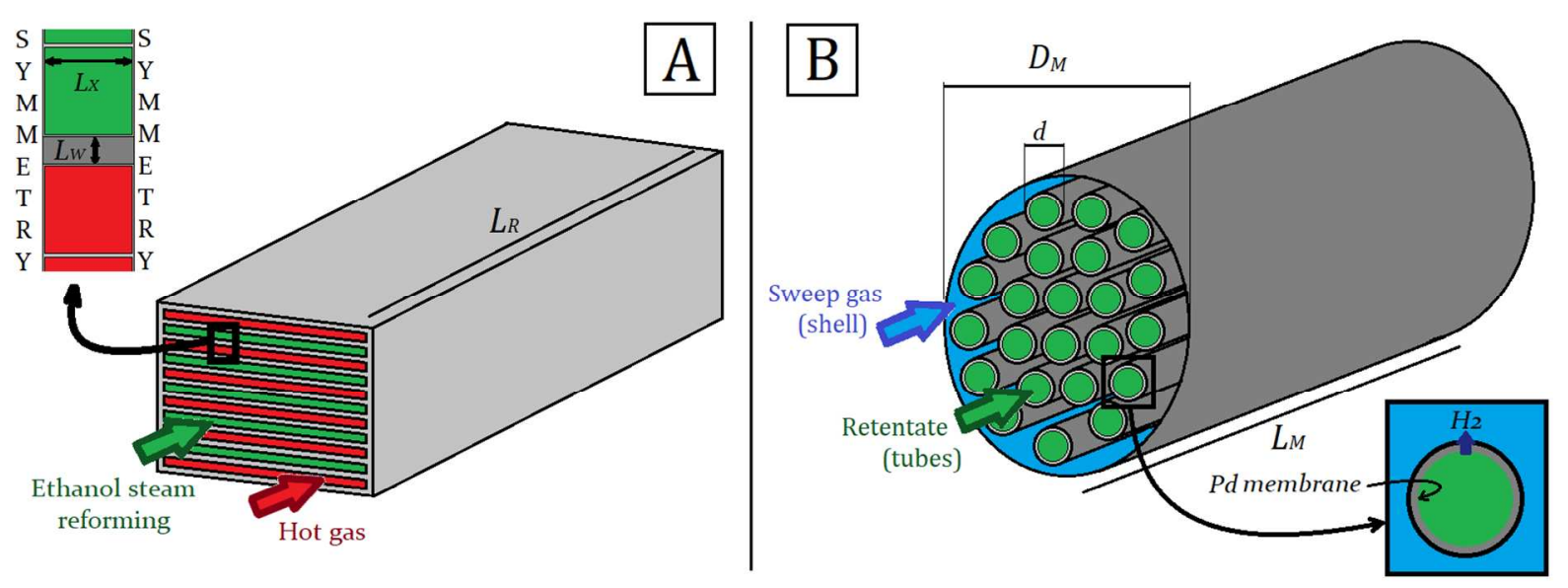

Figure 8. A) Parallel plates reactor. B) Shell and tubes membrane separator.

The mathematical model that represents the reactor includes the following equations:

\section{$\underline{\text { ESR side }}$}

Mass balance in the gas phase

$$
\begin{aligned}
\frac{d F_{i}}{d z}=A_{T} \cdot k_{g i} \cdot a_{v} \cdot\left(C_{i}^{S}-C_{i}\right), \quad F_{i}(0)=F_{i}^{0}, \\
i=C_{2} \mathrm{H}_{5} \mathrm{OH}, \mathrm{H}_{2} \mathrm{O}, \mathrm{H}_{2}, \mathrm{CO}_{2}, \mathrm{CH}_{4}, \mathrm{CO}, \mathrm{C}_{2} \mathrm{H}_{4} \mathrm{O}
\end{aligned}
$$

Mass balance in the catalyst

$$
k_{g i} \cdot a_{v} \cdot\left(C_{i}^{S}-C_{i}\right)=\sum_{k}\left(v_{i, k} \cdot r_{k}\right), \quad i=C_{2} H_{5} \mathrm{OH}, \mathrm{H}_{2} \mathrm{O}, \mathrm{H}_{2}, \mathrm{CO}_{2}, \mathrm{CH}_{4}, \mathrm{CO}, \mathrm{C}_{2} \mathrm{H}_{4} \mathrm{O}
$$


Energy balance in the gas phase

$$
\frac{d T}{d z}=\frac{h \cdot a_{v} \cdot\left(T^{s}-T\right)}{F_{T} \cdot C_{P}}, \quad T(0)=T^{0}
$$

Energy balance in the catalyst

$$
\left(n \cdot a_{v}\right) \cdot h \cdot\left(T^{s}-T\right)+q_{w}=-\left(n \cdot a_{v}\right) \cdot \sum_{k}\left(r_{k} \cdot \Delta H_{k}\right)
$$

Hot gas side

Energy balance in the gas phase

$$
\frac{d T_{H G}}{d z}=\frac{h_{H G} \cdot a_{v} \cdot\left(T_{H G}^{S}-T_{H G}\right)}{F_{T, H G} \cdot C_{P, H G}}, \quad T_{H G}(0)=T_{H G}^{0}
$$

Energy balance in the ceramic

$$
\left(n \cdot a_{v}\right) \cdot h_{H G} \cdot\left(T_{H G}^{S}-T_{H G}\right)+q_{w}=0
$$

$\underline{\text { Metallic wall }}$

Energy balance

$$
\frac{\partial^{2} T_{w}}{\partial z^{2}}+\frac{\partial^{2} T_{w}}{\partial x^{2}}=0
$$

Heat transferred

$$
\begin{gathered}
q_{w H G}=a_{v, w} \cdot \lambda_{w} \cdot \frac{\partial T_{w}}{\partial x}(\forall z, x=0) \\
q_{w E S R}=-a_{v, w} \cdot \lambda_{w} \cdot \frac{\partial T_{w}}{\partial x}\left(\forall z, x=L_{X}\right) \\
T_{w}(x=0)=T_{H G}^{S} \\
T_{w}\left(x=L_{X}\right)=T^{s}
\end{gathered}
$$

The reaction rate expressions $\left(\mathrm{r}_{\mathrm{k}}\right)$ accounting for the ethanol steam reforming are those reported in Section 3. Transport coefficients ( $h$ and $k_{g}$ ) are obtained from correlations reported in literature ${ }^{30}$. Additional details and description on this model can be found elsewhere ${ }^{31}$. 


\subsection{Hydrogen purification unit}

A membrane separator is intended here towards $\mathrm{H}_{2}$ purification (Fig. 8B). The unit comprises concentric membrane tubes inside an adiabatic shell where superheated steam is fed as sweep gas (stream 14) ${ }^{32}$. The use of water as sweep gas enables an easy way of separating the permeated hydrogen through refrigeration and flash units (see Fig. 7). Moreover, in this way, a significant amount of the required water can be recovered and reused. The membrane tubes consist of a dense Pd layer over a porous ceramic support. The permeation process is assumed to be infinitely selective towards hydrogen. A onedimensional model has been selected to simulate the steady-state operation of the permeation unit, with the consideration of isobaric axial evolution. It is important to remark that the model is non-isothermal, which is not a frequent assumption in membrane models. This allows to consider the activation by temperature of the Pd-based membrane along the axial coordinate. The mathematical model that represents the membrane separator comprises the following equations:

\section{Shell side}

Mass balance

$$
\left\{\begin{array}{c}
\frac{d F_{i}}{d z}=0 \\
\frac{d F_{H_{2}}}{d z}=-n_{T} \cdot \pi \cdot d \cdot J_{H_{2}}
\end{array}\right.
$$

Energy balance

$$
\frac{d T}{d z}=\frac{-n_{T} \cdot \pi \cdot d \cdot U \cdot\left(T-T^{P}\right)}{F_{T} \cdot C_{P}}, \quad T(0)=T\left(L_{R}\right)
$$




\section{$\underline{\text { Tubes side }}$}

Mass balance

$$
\left\{\begin{array}{cc}
\frac{d F_{H_{2}}^{P}}{d z}=n_{T} \cdot \pi \cdot d \cdot J_{H_{2}} & F_{H_{2}}^{P}(0)=0 \\
\frac{d F_{H_{2} O}^{P}}{d z}=0 & F_{H_{2} O}^{P}(0)=F_{H_{2} O}^{P, 0}
\end{array}\right.
$$

Energy balance

$$
\frac{d T^{P}}{d z}=\frac{n_{T} \cdot \pi \cdot d \cdot U \cdot\left(T-T^{P}\right)}{F_{T}^{P} \cdot C_{P}^{P}}, \quad T^{P}(0)=T^{P, 0}
$$

The hydrogen permeation flux through the membrane is quantified by the Sievert's Law ${ }^{33}$ :

$$
J_{H_{2}}=\frac{Q_{0} \cdot \exp \left(-\frac{E_{P}}{R \cdot T}\right)}{\delta} \cdot\left(\sqrt{p_{H_{2}}}-\sqrt{p_{H_{2}}^{P}}\right)
$$

The heat transfer coefficient $(U)$ and permeation parameters $\left(Q_{0}, E_{P}\right.$ and $\left.\delta\right)$ were evaluated according to ref. $^{34}$.

\subsection{Combustion chamber, heat exchangers and water separator}

A combustion chamber is included in the process both to preheat the reactor feed and to provide the reaction heat by taking advantage of the calorific value of the components in the retentate stream exiting the membrane separator (i.e., $\mathrm{CH}_{4}, \mathrm{CO}$, retentate $\mathrm{H}_{2}$ and unconverted ethanol and acetaldehyde). The unit is modeled as an adiabatic chamber in which the retentate (stream 4) is co-fed with air in excess (stream 11) already preheated using the hot exhaust of the reactor (stream 8). The stream exiting the chamber (stream 6) is profited to evaporate and preheat the reactor process inlet stream (stream 2) up to the desired thermal level (HEX1). Then, the outlet stream of the heat exchanger (stream 7) enters in the alternate channels to provide the reaction heat through the metallic walls of the reactor. 
The heat exchangers (HEX1, HEX2 and HEX3) are designed and simulated through enthalpy balances between the streams. The water recuperator is a simple isothermal flash unit, which was also simulated through enthalpy balances.

\subsection{Process simulation}

The proposed process was simulated with gPROMS ${ }^{35,36}$. The system is fed with a stream of $29 \mathrm{~mol} / \mathrm{h}$ of a solution of water and ethanol with a molar ratio of $6: 1$, pressure of 1.13 bar and temperature of $25^{\circ} \mathrm{C}$ (stream 1, Fig. 7) aiming to achieve a production of $\mathrm{H}_{2}$ of $10 \mathrm{~mol} / \mathrm{h}$ to be fed into a fuel cell (stream 17, Fig. 7). Both fresh water and air streams (streams 12 and 10, respectively) are fed to the process at a pressure of 1.13 bar and temperature of $25^{\circ} \mathrm{C}$. The steam flowrate fed to the membrane unit (stream 14) is calculated to fulfill a molar ratio of 1.5 in relation to the reformate flowrate exiting the reactor (stream 3). In fact, the aim here is to ensure a low hydrogen partial pressure in the permeation side of the membrane unit. On the other hand, air flowrate $\left(\mathrm{F}_{10}\right)$ is calculated by setting an air excess of $40 \%$ in the combustion chamber to ensure a complete conversion of fuels and to obtain an outlet stream of the combustion chamber with an energetic content $\left(\mathrm{F}_{6} \cdot \mathrm{h}_{6}\right)$ high enough to heat up the stream 1 up to the reaction condition and avoid an excessive cooling in the parallel plates reactor. The inlet temperature of the hot gases to the reactor (stream 7) is controlled by means of a by-pass in the heat exchanger HEX3 which regulates the preheating of stream 11 (see Fig. 7).

Thermal efficiencies for the overall process was defined as follows, with respect to lower heating values (LHV) and higher heating values (HHV):

$$
\begin{aligned}
\eta^{L} & =\frac{F_{\mathrm{H}_{2} \text { to PEM }} \cdot L H V_{\mathrm{H}_{2}}}{F_{\mathrm{C}_{2} \mathrm{H}_{5} \mathrm{OH}}^{0} \cdot L H V_{C_{2} \mathrm{H}_{5} \mathrm{OH}}} \\
\eta^{H} & =\frac{F_{\mathrm{H}_{2} \text { to PEM }} \cdot H H V_{\mathrm{H}_{2}}}{F_{C_{2} \mathrm{H}_{5} \mathrm{OH}}^{0} \cdot H H V_{\mathrm{C}_{2} \mathrm{H}_{5} \mathrm{OH}}}
\end{aligned}
$$


where $F_{H_{2}}$ to PEM is the flowrate of $\mathrm{H}_{2}$ fed to the PEM fuel cell, $L H V_{H_{2}}$ and $H H V_{H_{2}}$ are the lower and higher heating values of hydrogen, $F_{C_{2} \mathrm{H}_{5} \mathrm{OH}}^{0}$ is the ethanol flowrate fed to the process, and $L H V_{\mathrm{C}_{2} \mathrm{H}_{5} \mathrm{OH}}$ and $\mathrm{HHV}_{\mathrm{C}_{2} \mathrm{H}_{5} \mathrm{OH}}$ are the lower and higher heating values of ethanol.

The hydrogen permeation effectiveness is quantified by means of a recovery factor, $R$, which represents the ratio of permeated to fed hydrogen flowrates in the membrane unit:

$$
R_{H_{2}}=\frac{F_{H_{2}}^{P}}{F_{H_{2}}} \cdot 100
$$

The design parameters of the parallel plates reactor and the membrane unit are presented in Tables 7.

\begin{tabular}{|l|l|l|l|l|l|}
\hline \multicolumn{2}{|l|}{ Parallel plates reactor } & \multicolumn{4}{l|}{ Membrane separator } \\
\hline $\mathrm{n}$ & 300 & $\mathrm{n}_{\mathrm{T}}$ & 30 & $\mathrm{U}$ & $15 \mathrm{~W} / \mathrm{m}^{2} \cdot \mathrm{K}$ \\
\hline $\mathrm{L}_{\mathrm{X}}$ & $1.1 \mathrm{~mm}$ & $\mathrm{~d}$ & $13.4 \mathrm{~mm}$ & $\mathrm{Q}_{0}$ & $7.7 \cdot 10^{-5} \mathrm{~mol} /\left(\mathrm{s} \cdot \mathrm{m} \cdot \mathrm{bar}^{0.5}\right)$ \\
\hline $\mathrm{L}_{\mathrm{R}}$ & $0.18 \mathrm{~m}$ & $\mathrm{~L}_{\mathrm{M}}$ & $0.18 \mathrm{~m}$ & $\mathrm{E}_{\mathrm{P}}$ & $16300 \mathrm{~J} / \mathrm{mol}$ \\
\hline $\mathrm{L}_{\mathrm{W}}$ & $1.0 \mathrm{~mm}$ & $\mathrm{D}_{\mathrm{M}}$ & $0.11 \mathrm{~m}$ & $\delta$ & $60 \mu \mathrm{m}$ \\
\hline
\end{tabular}

Table 7. Design parameters of the parallel plates reactor and the membrane unit.

Figure 9 shows results of the simulation of the integrated $\mathrm{H}_{2}$ production process for one of the studied cases (Case A). In addition, Table 8 presents the main results of the complete process simulation with the above-specified operating conditions. The selected reactor design, operating with $T^{0}=600^{\circ} \mathrm{C}$ and $T_{H G}^{0}=700^{\circ} \mathrm{C}$, leads to a high degree of thermal integration. In fact, as can be observed, in less than 2 $\mathrm{cm}$ from the reactor entrance, the temperature of the process and hot gases are completely coupled, letting the reactor transfer heat with minimal $\Delta T$ between adjacent sections but with high values of $\mathrm{q}_{\mathrm{w}}$ (heat per unit area). This design also avoids a high $\Delta T_{\text {inlet-outlet }}$ inside the reactor. The theoretical adiabatic temperature drop is of about $125 \mathrm{~K}$ due to the high endothermicity of the ESR reaction, while 
a $\Delta T \cong-50 \mathrm{~K}$ is observed here for the process stream. In the membrane unit, the operation is performed using superheated steam as sweep gas, which is profited not only for refrigerating the process gas stream, but mainly for lowering the hydrogen partial pressure to promote the permeation process.

Besides, vapor condensation is intended at the exit of the membrane unit to recover a water-saturated hydrogen stream, and to minimize the required fresh water flowrate (stream 12) which amounts only $11.5 \%$ of the feed to the separator. 

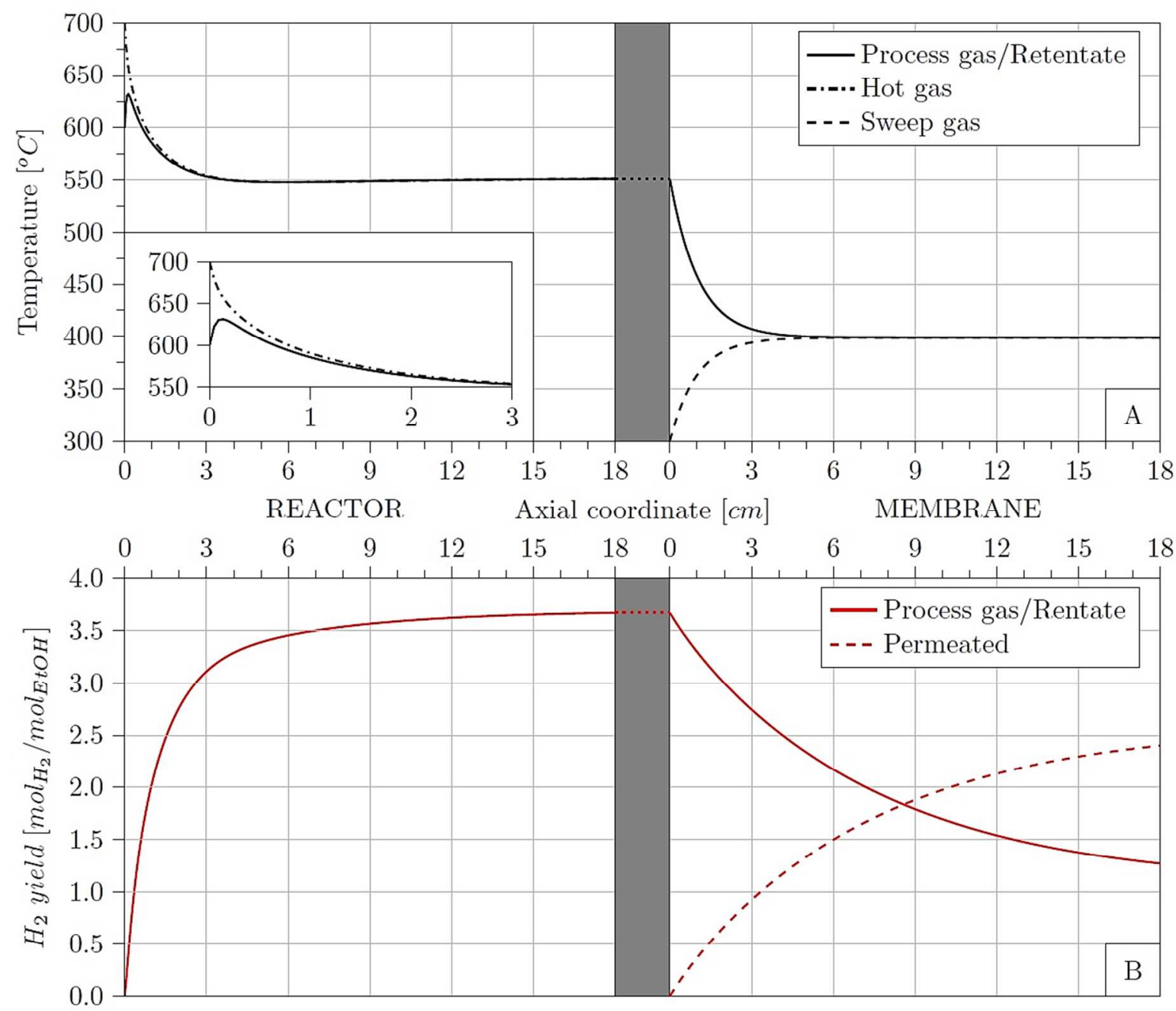

Figure 9. Temperature (A) and hydrogen yield (B) axial profiles in the reactor and membrane units, for Case A.

Additionally to Figure 9, Table 9 sums up the main indexes of the process performance for Case A. As seen, ethanol conversion in the reactor is slightly below $100 \%$. This is based on the global endothermicity of the reaction which makes the temperature drop, slowing the reaction rate down. However, the desired $\mathrm{H}_{2}$ production is achieved satisfactorily under the selected conditions. Furthermore, thanks to the use of steam as sweep gas, stream 17 is saturated in water at about $80^{\circ} \mathrm{C}$, which is a desired condition to feed a PEM fuel cell ${ }^{37}$. For this case, the permeated hydrogen yield is 
$2.40 \mathrm{~mol}_{\mathrm{H}_{2}} / \mathrm{mol}_{\mathrm{EtOH}}\left(R_{\mathrm{H}_{2}}=65.4 \%\right)$, which is below the value of $Y_{\mathrm{H}_{2}}=3.67$ obtained in the reactor, but, on the other hand, the membrane separator delivers a pure hydrogen stream to be fed directly to the cell. The achieved thermal efficiencies are in the range of those reported in literature ${ }^{14,15}$, although the fuel cell efficiency was not included in our calculation. This points a satisfactory performance of the hydrogen production system. Moreover, the energetic content of the off-gas (stream 9) would still be high enough to preheat an extra air stream to be fed to the fuel cell since it is at about $500^{\circ} \mathrm{C}$.

Results from two more simulation scenarios are presented in Table 9. Case B reports results of a system simulation fed with a lower flowrate of stream 1 ( $50 \%$ of Case A) aiming to achieve a closer approach to equilibrium in the ESR reaction and a higher residence time in the permeation unit. On the other hand, Case $\mathrm{C}$ comprises the same conditions of Case $\mathrm{A}$, except for the temperature of the hot gases feeding the reactor (stream 7), which is increased from $700^{\circ} \mathrm{C}$ up to $750^{\circ} \mathrm{C}$ to transfer heat at a higher thermal level, looking for an increase in the reaction rates.

The proposed process conditions showed good performance in terms of hydrogen production and thermal integration, achieving self-sufficiency in terms of energy for the three exposed cases. Case B shows an improved ethanol conversion in the reactor than Case A, with minimum augment in hydrogen yield and but a significant improvement in thermal efficiency due to the permeation performance. The augment of $\mathrm{Y}_{\mathrm{H} 2}$ in the reactor is not as relevant as it could be since $\mathrm{H}_{2}$ production via the MSR reaction is equilibrium-limited. Case $\mathrm{C}$, instead, leads to a similar conversion of ethanol than in Case $\mathrm{B}$, but the production of hydrogen improves regarding the other cases due to a higher thermal level in the reactor. Besides, in Case C, stream 9 (i.e., the off-gas) is obtained at a lower temperature while the hydrogen yield is augmented, which is another indicator of a higher degree of thermal integration. 
The almost-constant temperature of stream 17 and the low variability in the membrane recuperation for the hydrogen, for the different cases $\mathrm{A}-\mathrm{C}$, is a clear indication of the process robustness since, despite the system conditions, the design can still fulfill the required goals.

\begin{tabular}{|l|l|l|l|}
\hline Variable & Case A & Case B & Case C \\
\hline$X_{C_{2} H_{5} O H}$ after reaction [\%] & 99.04 & 99.7 & 99.7 \\
\hline$Y_{H_{2}}$ after reaction $\left[\mathrm{mol}_{\mathrm{H}_{2}} / \mathrm{mol}_{\mathrm{EtOH}}\right]$ & 3.67 & 3.69 & 3.92 \\
\hline$Y_{\mathrm{H}_{2}}$ after permeation $\left[\mathrm{mol}_{\mathrm{H}_{2}} / \mathrm{mol}_{\mathrm{EtOH}}\right]$ & 2.40 & 2.58 & 2.58 \\
\hline$R_{\mathrm{H}_{2}}[\%]$ & 65.4 & 70.0 & 65.7 \\
\hline$F_{\mathrm{H}_{2}}$ to PEM [mol $\left.\mathrm{H}_{2} / \mathrm{h}\right]$ & & & 10.69 \\
\hline$T_{\text {to }}$ PEM (stream 17$)\left[{ }^{\circ} \mathrm{C}\right]$ & 9.94 & 5.31 & 79.9 \\
\hline$F_{H_{2} O}$ (fresh) required $(\mathrm{stream} 12)[\%$ of total] & 11.5 & 79.2 & 12.2 \\
\hline$T_{\text {off-gas }}$ (stream 9 ) [ $\left.{ }^{\circ} \mathrm{C}\right]$ & 79.9 & 11.7 & 446.4 \\
\hline$\eta^{H}[\%]$ & 506.4 & 458.7 & 56.8 \\
\hline$\eta^{L}[\%]$ & 52.8 & 56.4 & 46.6 \\
\hline
\end{tabular}

Table 9. Main results of process simulation.

\section{Conclusions}

This work presents the study of a complete ethanol processor for hydrogen production through the kinetic study of a nickel-based catalyst and integrated process simulation. The selected structured catalyst showed satisfactory reaction performance operating at realistic process conditions $(P=1.13$ $\operatorname{bar}_{\mathrm{a}}, T=550-650^{\circ} \mathrm{C}, \tau=0-25 \mathrm{~h} \cdot \mathrm{g} / \mathrm{Nm}^{3}$, undiluted feed). In all reaction experiences negligible 
amounts of ethylene were observed in the gas phase. Additionally, carbon balances pointed a nonrelevant carbon deposition.

A phenomenological reaction system based on power-law-type expressions was used to describe the reaction behavior of the structured catalyst. The proposed scheme of reactions involves the decomposition of ethanol to acetaldehyde and water with the subsequent decomposition of acetaldehyde to $\mathrm{CO}$ and $\mathrm{CH}_{4}$, followed by the methane steam reforming and the water gas shift reactions. The collected experimental data were used to fit the kinetic parameters of the power-law reaction expressions (preexponential constants and activation energies). Moreover, activation energies were found to be in the range of those exposed by other authors.

The achieved reaction system was profited towards the simulation of the complete pure hydrogen generation process, including the ESR reactor, a hydrogen purification membrane unit, a combustion chamber and auxiliary heat exchangers. Results showed satisfactory thermal integration with efficiencies in the range from 43 to $47 \%$ based on LHV values and from 52 to $57 \%$ based on HHV values. For three different simulation scenarios, outlet streams of about $10 \mathrm{~mol} / \mathrm{h}$ of pure hydrogen were obtained, aiming the feed of a PEM fuel cell. The proposed scheme showed robustness in terms of hydrogen recuperation in the membrane, temperature to the fuel cell, fresh water required, accepted significant variations in the operating conditions, and it still maintained the process operability.

\section{Nomenclature}

$A_{T} \quad$ Cross-sectional area of flux in the parallel plates reactor. $\mathrm{m}^{2}$

$a_{v} \quad$ Specific area of the monolithic structure in the PPR. $\quad \mathrm{m}^{2} / \mathrm{m}^{3}$

$a_{v, w} \quad$ Specific area of heat transfer between zones in the PPR. $\quad \mathrm{m}^{2} / \mathrm{m}^{3}$

$C_{i} \quad$ Concentration of species $i$, in the gas phase. $\mathrm{mol} / \mathrm{m}^{3}$ 
$C_{i}^{S} \quad$ Concentration of species $i$, in the catalytic phase.

$\mathrm{mol} / \mathrm{m}^{3}$

$C_{P} \quad$ Heat capacity of gaseous streams in the parallel plates reactor.

$\mathrm{J} / \mathrm{mol} \cdot{ }^{\circ} \mathrm{C}$

$d \quad$ Diameter of tubes of the membrane separator.

$m$

$D_{e} \quad$ Effective diffusivity $m / s$

$E_{j} \quad$ Activation energy of reaction $j$.

$\mathrm{J} / \mathrm{mol}$

$E_{P} \quad$ Activation energy of the membrane.

$\mathrm{J} / \mathrm{mol}$

$F_{i} \quad$ Molar flow of species $i$.

$\mathrm{mol} / \mathrm{s}$

$F_{i}^{0} \quad$ Fed molar flow of species $i$.

$\mathrm{mol} / \mathrm{s}$

$h \quad$ Heat transport coefficient. $\quad W / m^{2} K$

$\Delta H \quad$ Enthalpy change of reaction. $\mathrm{J} / \mathrm{mol}$

$J_{H_{2}} \quad$ Flux of permeated hydrogen in the membrane separator. $\mathrm{mol} / \mathrm{s} \cdot \mathrm{m}^{2}$

$k_{g i} \quad$ Mass transport coefficient of species $i . \quad m / s$

$k_{j} \quad$ Kinetic constant of reaction $j$, at temperature $T$. See units in Tables 1 and 6.

$k_{j}^{0} \quad$ Preexponential constant of reaction $j$. See units in Tables 1 and 6.

$K_{e q, j} \quad$ Equilibrium constant of reaction $j . \quad m$

$L_{M} \quad$ Length of the membrane separator m

$L_{R} \quad$ Length of the parallel plates reactor $m$

$L_{W} \quad$ Width of the metallic wall of the parallel plates reactor. $m$

$L_{X} \quad$ Width of the channel of the monolith. $m$

$n \quad$ Number of channels of the monolith in the parallel plates reactor.

$n_{T} \quad$ Number of tubes in the membrane separator.

$p_{i} \quad$ Partial pressure of species $i$. 
$Q_{0} \quad$ Preexponential coefficient of permeation.

$q_{w} \quad$ Heat transferred between zones in the parallel plates reactor.

$R_{\mathrm{H}_{2}} \quad$ Hydrogen recovery factor

$r_{j} \quad$ Rate of reaction $j$.

$R \quad$ Universal constant of gases.

$R_{o} \quad$ Radius of catalyst particle

$T \quad$ Temperature of gas phase.

$T^{P} \quad$ Temperature of gas phase (permeated stream).

$T^{s} \quad$ Temperature of catalytic phase in the parallel plates reactor.

$T^{\text {ref }}$ Temperature of reference.

$T^{s} \quad$ Temperature of metallic phase in the parallel plates reactor.

$U$ Global heat transfer coefficient in the membrane separator.

$\dot{V} \quad$ Volumetric flow.

W Mass of catalyst.

$x \quad$ Transversal coordinate in the metallic wall of the parallel plates reactor.

$X_{i} \quad$ Conversion of reactant $i$.

$Y_{i} \quad$ Yield to product $i$.

z Axial coordinate.

$\delta \quad$ Thickness of membrane.

$\eta^{L} \quad$ Process thermal efficiency based on higher heating values.

$\eta^{H} \quad$ Process thermal efficiency based on lower heating values.

$\lambda_{w} \quad$ Metallic wall thermal conductivity in the of the parallel plates reactor. $\mathrm{mol} / \mathrm{s} \cdot \mathrm{m} \cdot \mathrm{bar}^{0.5}$

$W / m^{2}$

$\%$

$\mathrm{mol} / \mathrm{m}^{2} \cdot \mathrm{s}$

$\mathrm{J} / \mathrm{mol} \cdot \mathrm{K}$

$m$

$K$

K

K

K

K

$W / m^{2} \cdot K$

$\mathrm{Nm}^{3} / \mathrm{h}$

$m g$

m

$\%$

$\mathrm{mol} / \mathrm{mol}$

m

m

$\%$

$\%$

$W / m K$ 
$v_{i j} \quad$ Stoichiometric coefficient of species $i$ in the reaction $j$.
$\sigma \quad$ Parameter used to check mass transport limitation. See ref. ${ }^{17}$ for more information.
$\tau \quad$ Residence time.
$\quad \mathrm{h} \cdot \mathrm{g} / \mathrm{Nm}^{3}$

7. Acknowledgments

The authors acknowledge the financial support of Consejo Nacional de Investigaciones Científicas y Técnicas (CONICET), Universidad Nacional del Sur (UNS), and Agencia Nacional de Promoción Científica y Tecnológica (ANPCyT).

\section{References}

(1) Hosseini, S. E.; Wahid, M. A. Hydrogen Production from Renewable and Sustainable Energy Resources: Promising Green Energy Carrier for Clean Development. Renew. Sustain. Energy Rev. 2016, $57,850-866$.

(2) Kim, T. Micro Methanol Reformer Combined with a Catalytic Combustor for a PEM Fuel Cell. Int. J. Hydrogen Energy 2009, 34 (16), 6790-6798.

(3) Gardemann, U.; Steffen, M.; Heinzel, A. Design and Demonstration of an Ethanol Fuel Processor for HT-PEM Fuel Cell Applications. Int. J. Hydrogen Energy 2014, 39 (31), 18135-18145.

(4) Hernández, L.; Kafarov, V. Use of Bioethanol for Sustainable Electrical Energy Production. Int. J. Hydrogen Energy 2009, 34, 7041-4050.

(5) Zabed, H.; Sahu, J. N.; Suely, A.; Boyce, A. N.; Faruq, G. Bioethanol Production from Renewable Sources: Current Perspectives and Technological Progress. Renew. Sustain. Energy Rev. 2017, 71, 475-501.

(6) Wiloso, E. I.; Heijungs, R.; De Snoo, G. R. LCA of Second Generation Bioethanol: A Review 
and Some Issues to Be Resolved for Good LCA Practice. Renew. Sustain. Energy Rev. 2012, 16 (7), 5295-5308.

(7) Manzolini, G.; Tosti, S. Hydrogen Production from Ethanol Steam Reforming: Energy Efficiency Analysis of Traditional and Membrane Processes. Int. J. Hydrogen Energy 2008, 33, 5571-5582.

(8) García, E. Y.; Laborde, M. Á. Hydrogen Production by the Steam Reforming of Ethanol:

Thermodynamic Analysis. Int. J. Hydrogen Energy 1991, 16 (5), 307-312.

(9) Vaidya, P. D.; Rodrigues, A. E. Insight into Steam Reforming of Ethanol to Produce Hydrogen for Fuel Cells. Chem. Eng. J. 2006, 117 (1), 39-49.

(10) Contreras, J. L.; Salmones, J.; Colín-Luna, J. A.; Nuño, L.; Quintana, B.; Córdova, I.; Zeifert, B.; Tapia, C.; Fuentes, G. A. Catalysts for H2 Production Using the Ethanol Steam Reforming (a Review). Int. J. Hydrogen Energy 2014, 39, 18835-18853.

(11) Sharma, Y. C.; Kumar, A.; Prasad, R.; Upadhyay, S. N. Ethanol Steam Reforming for Hydrogen Production: Latest and Effective Catalyst Modification Strategies to Minimize Carbonaceous Deactivation. Renew. Sustain. Energy Rev. 2017, 74, 89-103.

(12) Viviente, J. L.; Meléndez, J.; Pacheco Tanaka, D. A.; Gallucci, F.; Spallina, V.; Manzolini, G.; Foresti, S.; Palma, V.; Ruocco, C.; Roses, L. Advanced M-CHP Fuel Cell System Based on a Novel Bio-Ethanol Fluidized Bed Membrane Reformer. Int. J. Hydrogen Energy 2017, 42 (19), $13970-13987$.

(13) Francesconi, J. A.; Oliva, D. G.; Aguirre, P. A. Flexible Heat Exchanger Network Design of an Ethanol Processor for Hydrogen Production. A Model-Based Multi-Objective Optimization Approach. Int. J. Hydrogen Energy 2017, 42 (5), 2736-2747.

(14) Francesconi, J. A.; Mussati, M. C.; Mato, R. O.; Aguirre, P. A. Analysis of the Energy Efficiency of an Integrated Ethanol Processor for PEM Fuel Cell Systems. J. Power Sources 2007, 167, 151- 
161.

(15) Salemme, L.; Menna, L.; Simeone, M. Thermodynamic Analysis of Ethanol Processors - PEM Fuel Cell Systems. Int. J. Hydrogen Energy 2010, 35 (8), 3480-3489.

(16) Palma, V.; Castaldo, F.; Ciambelli, P.; Iaquaniello, G. CeO2-Supported Pt/Ni Catalyst for the Renewable and Clean H2 Production via Ethanol Steam Reforming. Appl. Catal. B Environ. 2014, $145,73-84$.

(17) Gonzo, E. E. Criteria for Estimation of Transport Effects in a Network of Heterogeneous Catalytic Reactions. Lat. Am. Appl. Res. 1993, 23 (1), 1-9.

(18) De Groote, A. M.; Froment, G. F. Reactor Modeling and Simulations in Synthesis Gas Production. Rev. Chem. Eng. 1995, 11 (2), 145-183.

(19) PSE. GPROMS Advanced User Guide; Process Systems Enterprise Ltd.: London, 2004.

(20) Palma, V.; Castaldo, F.; Ciambelli, P.; Iaquaniello, G. CeO2-Supported Pt/Ni Catalyst for the Renewable and Clean H2 Production via Ethanol Steam Reforming. Appl. Catal. B Environ. 2014, $145,73-84$.

(21) Morgenstern, D. A.; Fornango, J. P. Low-Temperature Reforming of Ethanol over Copper-Plated Raney Nickel: A New Route to Sustainable Hydrogen for Transportation. Energy and Fuels 2005, $19(4), 1708-1716$.

(22) García, V. M.; López, E.; Serra, M.; Llorca Piqué, J. Dynamic Modeling of a Three-Stage LowTemperature Ethanol Reformer for Fuel Cell Application. J. Power Sources 2009, 192 (1), 208215.

(23) Mas, V.; Bergamini, M. L.; Baronetti, G.; Amadeo, N. E.; Laborde, M. Á. A Kinetic Study of Ethanol Steam Reforming Using a Nickel Based Catalyst. Top. Catal. 2008, 51, 39-48.

(24) Hou, K.; Hughes, R. The Kinetics of Methane Steam Reforming over a Ni/ $\alpha$-A12O Catalyst. 
Chem. Eng. J. 2001, 82 (May 2000), 311-328.

(25) Wei, J.; Iglesia, E. Isotopic and Kinetic Assessment of the Mechanism of Reactions of CH4with CO2or H2O to Form Synthesis Gas and Carbon on Nickel Catalysts. J. Catal. 2004, 224 (2), 370383.

(26) López, E.; Gepert, V.; Gritsch, A.; Nieken, U.; Eigenberger, G. Ethanol Steam Reforming Thermally Coupled with Fuel Combustion in a Parallel Plate Reactor. Ind. Eng. Chem. Res. 2012, $51,4143-4151$.

(27) Sahoo, D. R.; Vajpai, S.; Patel, S.; Pant, K. K. Kinetic Modeling of Steam Reforming of Ethanol for the Production of Hydrogen over Co/A12O3 Catalyst. Chem. Eng. J. 2007, 125, 139-147.

(28) Xu, J.; Froment, G. F. Methane Steam Reforming, Methanation and Water-Gas Shift .1. Intrinsic Kinetics. AIChE J. 1989, 35 (1), 88-96.

(29) Mbodji, M.; Commenge, J. M.; Falk, L. Preliminary Design and Simulation of a Microstructured Reactor for Production of Synthesis Gas by Steam Methane Reforming. Chem. Eng. Res. Des. 2014, $92(9), 1728-1739$.

(30) Cybulski, A.; Moulijn, J. A. Monoliths in Heterogeneous Catalysis. Catal. Rev. Sci. Eng. 1994, 36 (2), 179-270.

(31) Izurieta, E. M.; Borio, D. O.; Pedernera, M. N.; López, E. Parallel Plates Reactor Simulation: Ethanol Steam Reforming Thermally Coupled with Ethanol Combustion. Int. J. Hydrogen Energy 2017, 42, 18794-18804.

(32) Adrover, M. E.; López, E.; Borio, D. O.; Pedernera, M. N. Theoretical Study of a Membrane Reactor for the Water Gas Shift Reaction under Non-Isothermal Conditions. AIChE J. 2009, 55 (12), 3206-3213.

(33) Barbieri, G.; Brunetti, A.; Granato, T.; Bernardo, P.; Drioli, E. Engineering Evaluations of a 
Catalytic Membrane Reactor for the Water Gas Shift Reaction. Ind. Eng. Chem. Res. 2005, 44, $7676-7683$.

(34) Adrover, M. E.; López, E.; Borio, D. O.; Pedernera, M. N. Simulation of a Membrane Reactor for the WGS Reaction: Pressure and Thermal Effects. Chem. Eng. J. 2009, 154, 196-202.

(35) Oh, M.; Pantelides, C. C. A Modelling and Simulation Language for Combined Lumped and Distributed Parameter Systems. Comput. Chem. Eng. 1996, 20 (6-7), 611-633.

(36) PSE. GPROMS Introductory User Guide; Process Systems Enterprise Ltd.: London, 2004.

(37) Francesconi, J. A.; Mussati, M. C.; Aguirre, P. A. Effects of PEMFC Operating Parameters on the Performance of an Integrated Ethanol Processor. Int. J. Hydrogen Energy 2010, 35, 5940-5946. 


\section{Abstract Graphics}
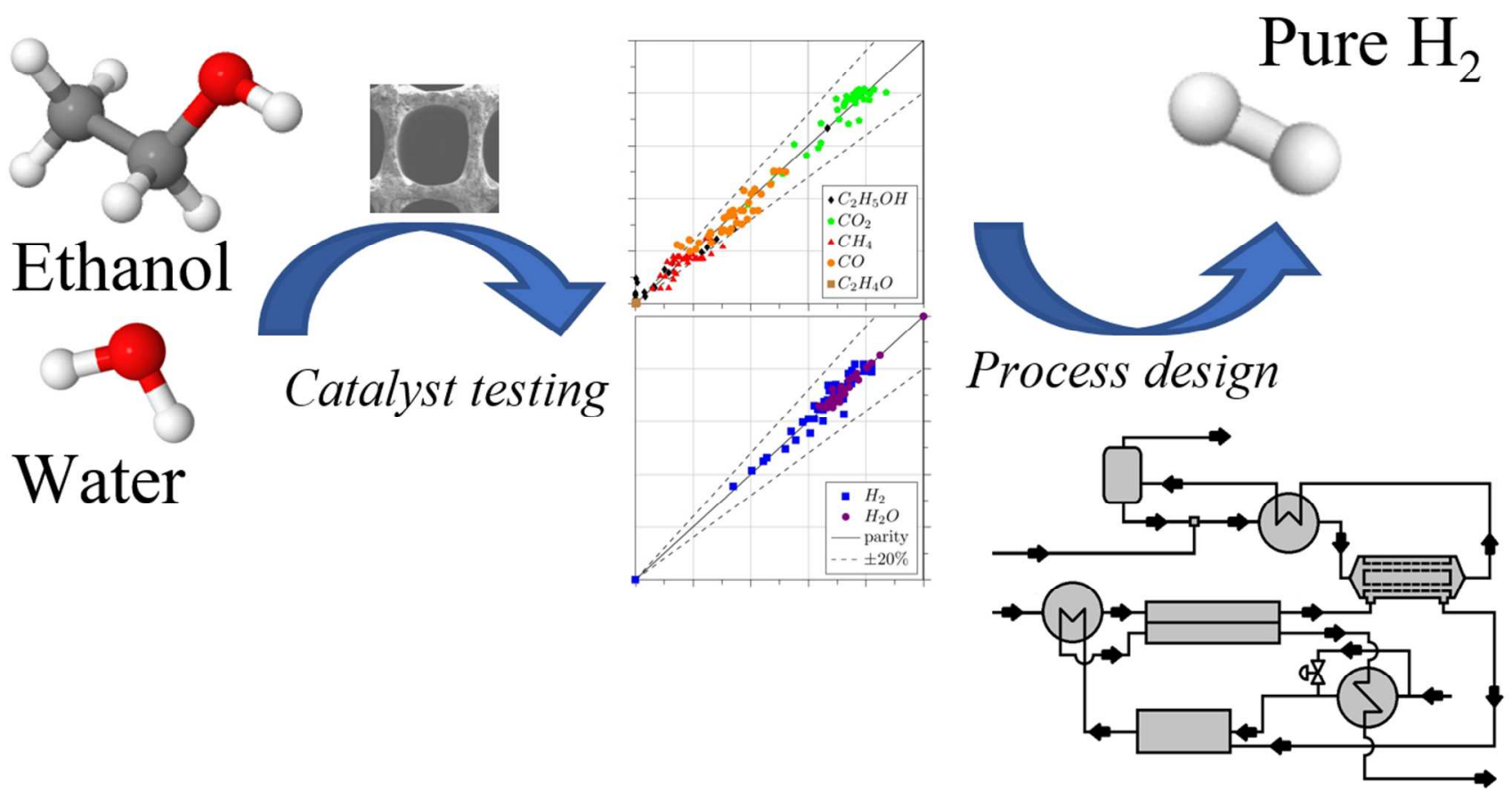